British Journal of Haematology, 1976, 32, 159.

\title{
The Interaction of $\propto$-Thalassaemia and Haemoglobin G Philadelphia
}

\author{
R. F. Rieder, D.H. WoodburY* and D. L. RuckNagel* \\ Department of Medicine, State University of New York, Downstate Medical Center, \\ Brooklyn, N.Y., U.S.A., and *Departments of Internal Medicine and Human Genetics, \\ University of Michigan Medical School, Ann Arbor, Michigan, U.S.A.
}

(Received I5 July 1975; accepted for publication 5 August 1975)

\begin{abstract}
Summary. An American Negro woman was found to have $\mathrm{HbH}$ disease in association with $\mathrm{HbG}$ Philadelphia ( $\alpha 68$-asn $\rightarrow$ lys). Starch gel electrophoresis failed to reveal the presence of any $\mathrm{HbA}$ or $\mathrm{HbA}_{2}$ and studies of globin chain synthesis indicated absence of $\alpha^{\mathrm{A}}$ production. The $\alpha^{\mathrm{G}} / \beta$ synthesis ratio was 0.63 . The woman's son and her two half-sibs had $\alpha$-thalassaemia trait with no $\mathrm{HbH}$ and $\alpha / \beta$ synthesis ratios of $0.84,0.84$ and 0.76 . The data indicate that there is no functioning $\alpha^{\mathrm{A}}$ gene linked to the $\alpha^{\mathrm{G}}$ gene. The absence of $\alpha^{\mathrm{A}}$ synthesis by the propositus also indicates that the $\alpha$-thalassaemia gene trans to the $\alpha^{G}$ gene completely suppresses $\alpha$ chain production, the first evidence for such a gene in Negroes.
\end{abstract}

The $\alpha$-thalassaemias are a group of disorders of varying clinical severity characterized by different degrees of decreased synthesis of the $\alpha$ polypeptide chain of human haemoglobin (Wasi et al, 1974). The most severe form of the disease, seen primarily in Asians, results in still-birth with hydrops fetalis and a haemoglobin composition almost exclusively $\mathrm{Hb}$ Bart's, a $\gamma^{4}$ tetramer (Luan Eng et al, r962; Hunt \& Lehmann, I959). A milder disorder, HbH disease, is characterized by slight to moderate haemolytic anaemia and the presence of $5-30 \%$ of $\mathrm{HbH}$, a $\beta 4$ tetramer (Rigas et al, I956; Jones \& Schroeder, I963). $\alpha$-Thalassaemia trait is usually associated with no clinical manifestations except for erythrocyte hypochromia (Wasi et al, 1974).

The genetic bases for these syndromes have not been conclusively determined. In one scheme that has been proposed, the Hb Bart's-hydrops fetalis disorder results from homozygosity for a gene $\left(\alpha-\right.$ thal $_{1}$ ) which causes complete suppression of $\alpha$ globin synthesis (Pootrakul et al, 1967). $\mathrm{HbH}$ disease would be due to heterozygosity for $\alpha$-thal ${ }_{1}$ and a gene ( $\alpha$-thal ${ }_{2}$ ) which directs a partially depressed level of $\alpha$ chain production (Wasi et al, I964). Simple heterozygosity for $\alpha$-thal ${ }_{1}$ would result in $\alpha$-thalassaemia trait. There is evidence that in some human populations (Hollán et al, 1972), but not all (Abramson et al, 1970), $\alpha$ globin synthesis is directed by two linked structural loci. Accordingly, it has been postulated that classic $\alpha$-thalassaemia trait, $\mathrm{HbH}$ disease, and the hydrops fetalis syndrome, respectively, result from the presence of a total of two, three or four equivalent thalassaemia genes at the $4 \alpha$ structural sites on the chromosome pair (Lehmann, 1970).

Correspondence: Dr R. F. Rieder, SUNY-Downstate Medical Center, 450 Clarkson Avenue, Brooklyn, N.Y. II 203 , U.S.A. 
Although the frequent occurrence of small amounts of $\mathrm{Hb}$ Bart's in the neonatal period suggests a high incidence of the gene for $\alpha$-thalassaemia in Negroes (Weatherall, 1963; Folayan Esan, $\mathrm{r} 97 \mathrm{O}), \mathrm{HbH}$ disease is considered rare in that race and the $\mathrm{Hb}$ Bart's-hydrops fetalis syndrome has never been reported. As a result it has been postulated that the $\alpha$ thalassaemia genes in Negroes differ from those in Asians and do not totally suppress $\alpha$ chain synthesis (Stamatoyannoupoulos, 1972). A haematological study and an investigation of haemoglobin synthesis in an American Negro woman with HbG Philadelphia ( $\alpha 68$ asn $\rightarrow$ lys)$\mathrm{HbH}$ disease, and in members of her family, has provided additional information on the genetics of $\alpha$-thalassaemia.

\section{METHODS}

Haematological methods. Haematological studies were carried out using standard methods (Cartwright, I968).

Haemoglobin analysis. Haemoglobin electrophoresis on starch gel at $\mathrm{pH} 8.5$ and $\mathrm{pH} 7.0$ was performed as described by Weatherall \& Clegg (I972). The level of $\mathrm{HbF}$ was determined by the method of Betke et al (1959) and the level of $\mathrm{HbA}_{2}$ by the method of Bernini (I969). $\mathrm{HbH}$ was quantitated by photometric scanning of cellulose acetate electrophoretic strips (Helena Laboratories, Beaumont, Texas). The separation of globin chains on carboxymethylcellulose columns in $8 \mathrm{M}$ urea and fingerprint analysis were performed as previously described (Clegg et al, 1966).

Haemoglobin synthesis. Globin chain biosynthesis was studied by in vitro incubation of peripheral blood for $30 \mathrm{~min}$ in the presence of $\left[{ }^{3} \mathrm{H}\right]$ leucine (Rieder, I97I). Globin was prepared immediately from the entire haemolysate including membranes. After separation of the chains by carboxymethylcellulose chromatography (Clegg et al, 1966), incorporated radioactivity was measured by liquid scintillation counting.

\section{RESULTS}

The propositus (II-4, Table I) is 28 years old and healthy but has known of mild anacmia and abnormal haemoglobin for several years. Her peripheral blood film is typical of $\mathrm{HbH}$ disease with marked anisocytosis, poikilocytosis, microcytosis and hypochromia (Table I). Incubation of her erythrocytes with new methylene blue resulted in the formation of multiple inclusions ( $\mathrm{HbH}$ bodies) in almost all cells (Rigas et al, I956; Cartwright, 1968). Starch gel electrophoresis at $\mathrm{pH}$ 8.6 (Weatherall \& Clegg, I972) revealed haemoglobin bands in the position of $\mathrm{HbH}$, $\mathrm{HbG}$ Philadelphia (Weatherall et al, $\mathrm{I} 962$ ) and $\mathrm{HbG}_{2}\left(\alpha_{2}{ }^{\mathrm{G}} \delta_{2}\right)$ (Fig I). No $\mathrm{HbA}$ or $\mathrm{HbA}_{2}$ was evident. The level of $\mathrm{HbH}$ was $3.5-7.1 \%$ when measured by cellulose acetate electrophoresis. Starch gel electrophoresis at $\mathrm{pH} 7.0$ (Weatherall \& Clegg, 1972) and fingerprint and amino acid analyses confirmed the presence of $\mathrm{HbH}$ and $\mathrm{HbG}$ Philadelphia (Baglioni \& Ingram, I96I).

The son of the propositus (III-I, Table I) is mildly anaemic (PCV 0.352) with hypochromic, microcytic red blood cells ( $\mathrm{MCH}$ I $8.8 \mathrm{pg}, \mathrm{MCV} 63 \mathrm{fl}$ ). The peripheral blood film was characteristic of thalassaemia trait. A rare cell with inclusion bodies was noted after incubation with new methylene blue. Starch gel electrophoresis at $\mathrm{pH} 8.6$ revealed only $\mathrm{HbA}$ and $\mathrm{HbA}_{2}$. The level of $\mathrm{HbA}_{2}$ was normal $(2.7 \%)$ when measured by DEAE-cellulose chromatography 


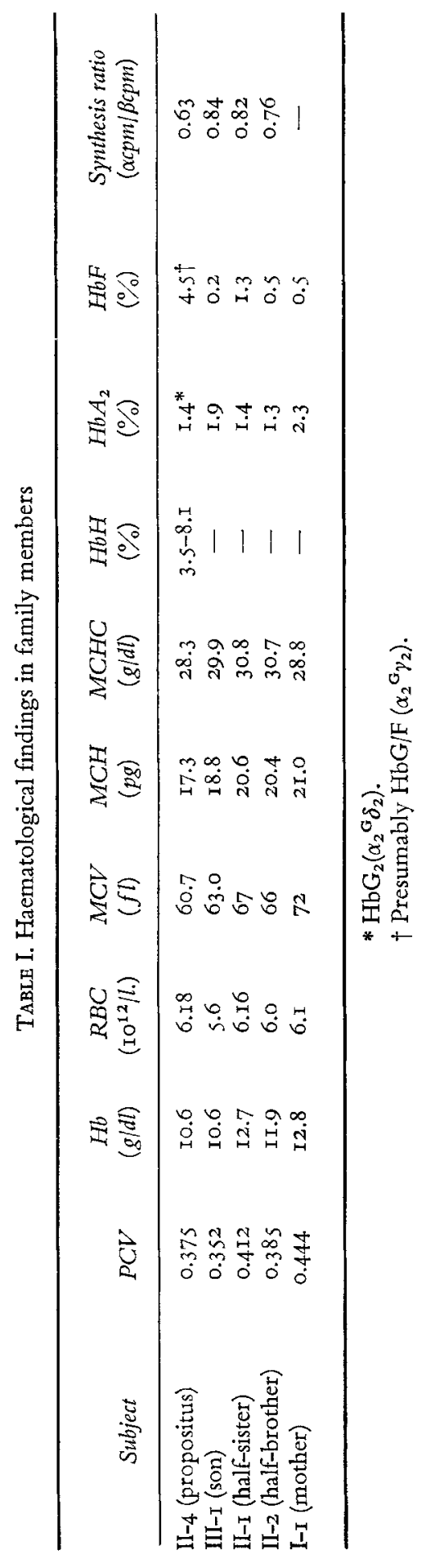




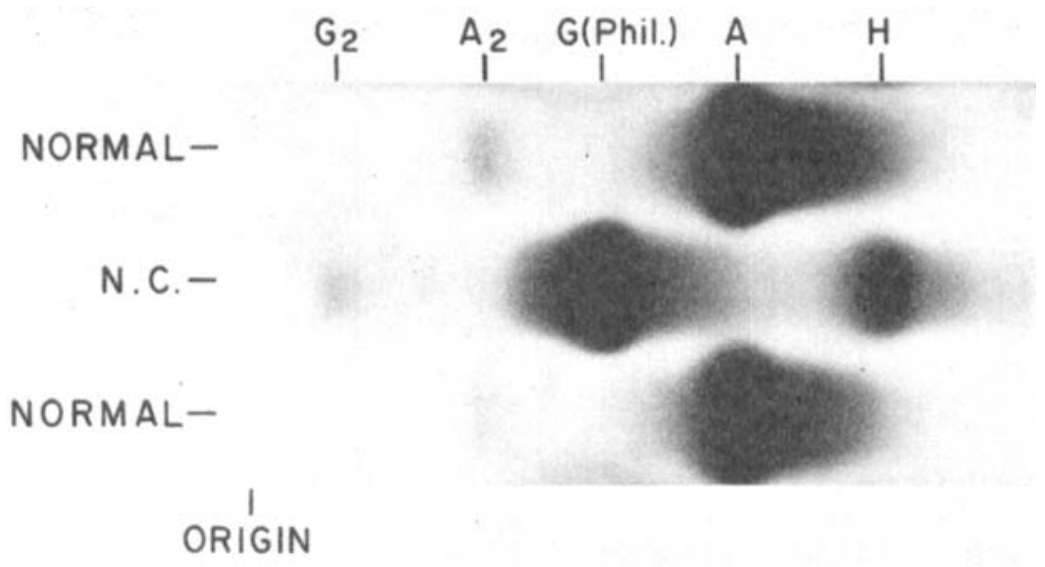

FIG I. Starch gel electrophoresis in Tris-EDTA-borate buffer, $\mathrm{pH}$ 8.6, of haemolysates from normal individual (normal) and propositus (N.C.) with HbG Philadelphia-HbH disease, stained with Amido Black. The anode is towards the right.

(Bernini, I969). No HbH was demonstrated by haemoglobin electrophoresis on starch gel at $\mathrm{pH}$ 7.o. Haematological examination of the mother (I-I, Table I), a half-sister and a halfbrother (II-I, II-2, Table I) of the propositus gave results similar to those found in the son. All these subjects had evidence of $\alpha$-thalassaemia trait with very slight anaemia, moderate anisocytosis, poikilocytosis, microcytosis and hypochromia with normal levels of $\mathrm{HbA}_{2}$ and $\mathrm{HbF}$ (Table I).

Haemoglobin synthesis was studied in vitro in the peripheral blood of the propositus and her relatives. Fig 2 shows the column chromatographic separation of radioactive $\beta$ and $\alpha^{\mathbf{G}}$ globin from the blood of the propositus. There was deficient synthesis of $\alpha^{\mathrm{G}}$ globin relative

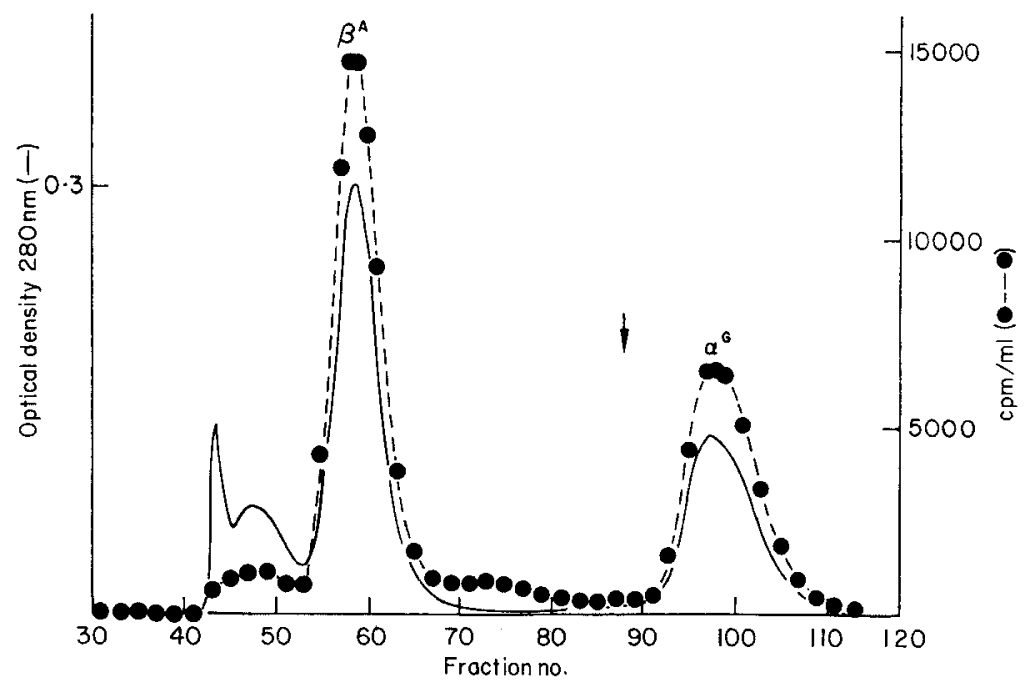

FIG 2. Carboxymethyl cellulose chromatography of radioactive globin prepared from the blood of the subject with $\mathrm{HbG}$ Philadelphia-HbH disease. The arrow indicates the position expected for $\alpha^{\mathrm{A}}$. The $\alpha^{\mathbf{G}} / \beta$ synthesis ratio is $0.6 \mathrm{I}$. 
to $\beta$ globin; in two experiments the $\alpha^{\mathrm{G}} / \beta$ synthesis ratios were 0.66 and 0.63 (Table I). These results are similar to the $\alpha / \beta$ synthesis ratios previously reported in studies of haemoglobin synthesis in Negroes with $\mathrm{HbH}$ disease (Schwartz \& Atwater, 1972) but are somewhat higher than reported in other racial groups (Kan et al, 1968). There was no evidence of any $\alpha^{\mathrm{A}}$ production by the erythrocytes of the propositus (Fig 2).

Globin chain synthesis was also unbalanced in the blood of the son (III-I). The $\alpha / \beta$ synthesis ratio was 0.84 (Table I). Similar results were obtained when blood specimens from the halfsister $(\alpha / \beta=0.82)$ and half-brother $(\alpha / \beta=0.76)$ of the propositus were incubated (Table I). The results are similar to the synthetic ratios reported in $\alpha$-thalassaemia trait.

\section{DISCUSSION}

The haematological and biosynthetic studies indicate that this propositus with $\mathrm{HbH}$ disease is heterozygous for $\alpha$-thalassaemia and the structural mutant, $\alpha^{\mathbf{G}}$ Philadelphia. It seems certain that the son inherited $\alpha$-thalassaemia trait from his mother and that she received it from her mother. The other two relatives of the propositus also appear to be carriers of $\alpha$-thalassaemia trait. The failure to demonstrate $\mathrm{HbA}$, or any synthesis of $\alpha^{\mathrm{A}}$, in the blood of the propositus indicates that the $\alpha$-thalassaemia gene situated trans to $\alpha^{\mathrm{G}}$, is of the type that results in complete suppression of $\alpha$ globin production. This is the first demonstration of such a gene in the Negro race. In addition, the absence of $\mathrm{HbA}$ indicates that there is also no functioning $\alpha^{\mathrm{A}}$ gene linked on the chromosome bearing the $\alpha^{G}$ Philadelphia gene in the propositus. Because some heterozygotes for HbG Philadelphia (Rucknagel \& Dublin, I974) possess more abnormal haemoglobin (40\%) in their erythrocytes than is usual for an $\alpha$ chain mutant $(20-25 \%)$ it has been suggested that the $\alpha^{\mathrm{G}}$ Philadelphia gene is located on a chromosome that contains only one $\mathrm{Hb}_{\alpha}$ locus or is frequently linked to an $\alpha$-thalassaemia gene (French \& Lehmann, 197I). Either hypothesis would explain why the propositus manifested $\mathrm{HbH}$ disease while her son who inherited the opposite chromosome and its $\alpha$-thalassaemia gene had only $\alpha$-thalassaemia trait. The biosynthetic studies also are suggestive of greater $\alpha / \beta$ imbalance in the mother than the son.

The haemoglobinopathy manifested by the propositus is thus similar to the syndrome in Asian subjects with $\mathrm{HbH}$ disease due to heterozygosity for $\mathrm{HbQ}$ and $\alpha$-thalassaemia (Luan Eng et al, 1966). No $\mathrm{HbA}$ is found in that disorder either. Apparently $\alpha^{\mathbf{Q}}$ is also linked to an $\alpha$-thalassaemia gene. In contrast, a Negro woman heterozygous for $\alpha$-thalassaemia and the $\alpha$ mutant $\mathrm{HbI}$, did not have $\mathrm{HbH}$ and demonstrated $30 \% \mathrm{HbA}$ (Atwater et al, I960). Her children inherited $\alpha$-thalassaemia trait, exhibiting 10\% $\mathrm{Hb}$ Bart's in the neonatal period (Atwater et al, I960). Possibly there is a functioning $\alpha^{A}$ gene linked to $\alpha^{I}$.

Studies of DNA-DNA hybridization suggest that in the hydrops fetalis-Hb Bart's syndrome there is deletion of $\alpha$ globin genetic material (Ottolenghi $e t a l$, 1974; Taylor et al, 1974). The simplest explanation for the present observations would be that normally two $\alpha$ genes are linked per chromosome. $\mathrm{HbH}$ disease occurs when an individual inherits one chromosome with both $\alpha$ genes deleted and one chromosome with one gene deleted. Recently published DNA hybridization data support this possibility (Kan et al, I975). Both the $\alpha^{\mathrm{Q}}$ and $\alpha^{\mathrm{G}}$ Philadelphia genes seem to occur on chromosomes without a second functioning $\alpha$ globin gene. Whether a single chromosome (Rucknagel \& Dublin, I974) is synonymous 
with classic $\alpha$-thalassaemia remains to be seen. In any event when the chromosomes bearing these mutant $\alpha$ genes are paired with a chromosome having both $\alpha$ genes deleted, HbG Philadelphia-HbH disease or $\mathrm{HbQ}-\mathrm{HbH}$ disease results.

\section{ACKNOWLEDGMENTS}

This work was supported by grants (AMI240I and GMr54I9) from the United States Public Health Service. R.F.R. is a Career Scientist of the Irma T. Hirschl Charitable Trust.

\section{REFERENCES}

Abramson, R.K., Rucknagel, D.L., Shreffler, D.C. \& SaAve, J.J. (1970) Homozygous Hb J Tongariki: evidence for only one alpha chain structural locus in Melanesians. Science, 169, I94.

Atwater, J., Schwartz, I.R., Erslev, A.J., MontGOMERY, T.L. \& TOCANTINS, L.M. (1960) Sickling of erythrocytes in a patient with thalassemiahemoglobin-I disease. New England Journal of Medicine, 263, 1215 .

Baglioni, C. \& Ingram, V.M. (I96I) Abnormal human haemoglobins. V. Chemical investigations of haemoglobins $A, G, C, X$ from one individual. Biochimica et Biophysica Acta, 48, 253.

BERNINI, L.F. (I969) Rapid estimation of hemoglobin $\mathrm{A}_{2}$ by DEAE chromatography. Biochemical Genetics, 2, 305 .

BetKe, K., Marti, H.R. \& Schicht, I. (I959) Estimation of small percentages of foetal haemoglobin. Nature, 184, 1877 .

Cartwright, G.E. (I968) Diagnostic Laboratory Hematology, 4th edn. Grune \& Stratton, New York.

Clegg, J.B., Naughton, M.A. \& Weatherali, D.J. (r966) Abnormal human haemoglobins. Separation and characterization of the $\alpha$ and $\beta$ chains by chromatography and the determination of two new variants, $\mathrm{Hb}$ Chesapeake and $\mathrm{Hb} \mathrm{J}$ (Bangkok). Journal of Molecular Biology, 19, 91.

Folayan Esan, G.J. (I970) The thalassaemia syndromes in Nigeria. British Joumal of Haematology, I9, 47 .

French, E.A. \& LeHMANN, H. (I97I) Is haemoglobin Go Philadelphia linked to $\alpha$-thalassaemia? Acta Haematologica, 46, I49.

Hollán, S.R., Szelenyi, J.G., Brimhall, B., Duerst, M., Jones, R.T., Koler, R.D. \& Stocklen, Z. (1972) Multiple alpha chain loci for human haemoglobins: Hb J-Buda and Hb G-Pest. Nature, 235, 47.

Hunt, J.A. \& LeHMANN, H. (1959) Haemoglobin 'Bart's': a foetal haemoglobin without $\alpha$-chains. Nature, I84, 872 .

JONES, R.T. \& Schroeder, W.A. (1963) Chemical characterization and subunit hybridization of human hemoglobin $\mathrm{H}$ and associated compounds. Biochemistry, 2, I357.
Kan, Y.W., DozY, A.M., VARMUS, H.E., TAYlor, J.M., Holland, J.P., Lie-Injo, L.E., Ganesan, J. $\&$ TODD, D. (1975) Deletion of $\alpha$-globin genes in haemoglobin $\mathrm{H}$ disease demontrates multiple $\alpha$-globin structural loci. Nature, 255, 255.

Kan, Y.W., SchwarTz, E. \& Nathan, D.G. (I968) Globin chain synthesis in the alpha thalassemia syndromes. Journal of Clinical Investigation, 47, 2515 .

LehmanN, H. (I970) Different types of alpha-thalassaemia and significance of haemoglobin Bart's in neonates. Lancet, ii, 78 .

LUAN ENG, I.-I., GIE, L.H., AgER, J.A.M. \& LEHMANN, H. (I962) $\alpha$-Thalassaemia as a cause of hydrops foetalis. British Journal of Haematolog $y, 8$, I.

Luan Eng, L.-I., Pillay, R.P. \& Thuraisingham, V. (1966) Further cases of $\mathrm{Hb} \mathrm{Q}-\mathrm{H}$ disease (HbQ- $\alpha$ thalassemia). Blood, 28, 830 .

Ottolenghr, S., Lanyon, W.G., Paur, J., WILliamson, R., Weatherall, D.J., Clegg, J.B., Pritchard, J., Pootrakul, S. \& Boon, W.H. (I974) The severe form of $\alpha$ thalassaemia is caused by a haemoglobin gene deletion. Nature, 254, 369.

Pootrakul, S., Wast, P. \& Na-Nakorn, S. (I967) Haemoglobin Bart's hydrops foetalis in Thailand. Annals of Human Genetics, 30, 293.

RIEDER, R.F. (I97r) Synthesis of hemoglobin Gun Hill: increased synthesis of the heme-free $\beta^{\mathrm{GH}}$ globin chain and subunit exchange with a free $\alpha$-chain pool. Journal of Clinical Investigation, 50, 388 .

Rigas, D.A., Koler, R.D. \& Osgood, E.E. (1956) Hemoglobin H. Clinical, laboratory, and genetic studies of a family with a previously undescribed hemoglobin. Journal of Laboratory and Clinical Medicine, 47, $5 \mathrm{I}$.

Rucknager, D.L. \& Dublin, P.A., JR (1974) Hemoglobin $\mathrm{G} \alpha$-trait: evidence for heterogeneity in the number of alpha chain loci in man. (Abstract). American Journal of Human Genetics, 26, $73 \mathrm{~A}$.

Schwartz, E. \& Atwater, J. (1972) $\alpha$-Thalassemia in the American Negro. Journal of Clinical Investigation, 5I, 4I2.

Stamatoyannoupoulos, G. (1972) Hemoglobin $\mathrm{H}$ disease in the Afro-American: phenotypic and 
genetic considerations. Birth Defects: Original Article Series, 8, 29.

TaYlor, J.M., Dozy, A.M., Kan, Y.W., Varmus, H.E., Lie-INJo, L.E., Ganesan, J. \& Todd, D. (I974) Genetic lesion in homozygous $\alpha$-thalassemia (hydrops fetalis). Nature, 25r, 392.

Wast, P., Na-Nakorn, S. \& SuIngdumrong, A. (1964) Haemoglobin $H$ disease in Thailand: a genetical study. Nature, 204, 907.

Wast, P., Na-Nakorn, S. \& Pootrakul, S. (1974) The $\propto$ thalassaemias. Clinics in Haematology, 3, 383 .
Weatherali, D.J. (1963) Abnormal haemoglobins in the neonatal period and their relationship to thalassaemia. British Journal of Haematology, 9, 265.

Weatherall, D.J. \& ClegG, J.B. (I972) The Thalassaemia Syndromes, 2nd edn. Blackwell Scientific Publications, Oxford.

Weatherali, D.J., Sigler, A.T. \& Baglioni, C. (I962) Four hemoglobins in each of three brothers. Genetic and biochemical significance. Bulletin of the Johns Hopkins Hospital, III, 143. 